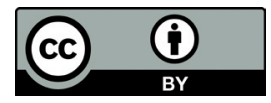

\title{
CERAMIC AND STONE BREAD STAMPS OF TAURICA. TO THE QUESTION OF THE ALLOCATION OF STYLISTIC GROUPS
}

\author{
Vadim V. Maiko \\ Institute of Archaeology of Crimea of the Russian Academy of Sciences, Simferopol, Russian Federation
}

\begin{abstract}
Introduction. Among the liturgical objects of the Byzantine Christian cult, liturgical bread stamps make up a special category. Despite the fact that they have become widespread on the territory of the Byzantine Empire since late antique and early medieval times, for medieval Crimea they remain a rare find. The source base of the work consists of 34 ceramic and limestone bread stamps, discovered in different years in almost all regions of medieval Taurica. Of these, only 3 copies were not introduced into scientific circulation, which greatly simplifies the work and avoids unnecessary repetitions. Bronze and wooden bread stamps, which have a pronounced originality, are not considered in this work. Methods and materials. The standard methods, which usually involved for the study of archaeological materials, are used in the work: stratigraphic, typological, and comparative. Analysis. Despite the fact that each bread stamp found on the peninsula has individual features, the work for the first time made an attempt to distinguish several stable stylistic groups. The main criterion is the design features of the objects and the arrangement of the elements forming the composition. Results. The data obtained made it possible to conclude that today we can talk about 8 groups in which stamps of different morphology are presented. The chronological scope of the occurrence and the period of existence of each of these groups is different. Archaeological complexes are also different, where products of a particular group were recorded. In quantitative terms, the groups are also not uniform. Some of them form single specimens of prosphores, others are more numerous.
\end{abstract}

Key words: medieval Taurica, bread stamps, ornamentation, chronology, stylistic groups.

Citation. Maiko V.V. Ceramic and Stone Bread Stamps of Taurica. To the Question of the Allocation of Stylistic Groups. Vestnik Volgogradskogo gosudarstvennogo universiteta. Seriya 4. Istoriya. Regionovedenie. Mezhdunarodnye otnosheniya [Science Journal of Volgograd State University. History. Area Studies. International Relations], 2021, vol. 26, no. 6, pp. 19-30. (in Russian). DOI: https://doi.org/10.15688/jvolsu4.2021.6.2

УДК 904(470)“6/15”

Дата поступления статьи: 20.05.2021

ББК 63.4(2)

Дата принятия статьи: 02.07.2021

\section{КЕРАМИЧЕСКИЕ И КАМЕННЫЕ ПРОСФОРНЫЕ ШТАМПЫ ТАВРИКИ. К ВОПРОСУ О ВЫДЕЛЕНИИ СТИЛИСТИЧЕСКИХ ГРУПП}

\section{Вадим Владиславович Майко}

Институт археологии Крыма РАН, г. Симферополь, Российская Федерация

\footnotetext{
Аннотация. Введение. Среди литургических предметов византийского христианского культа особую категорию составляют просфорные штампы. Несмотря на то что они получили распространение на территории Византийской империи еще с позднеантичного и раннесредневекового времени, для средневекового Крыма они остаются редкой находкой. Источниковую базу работы составляют 34 керамических и известняковых штампа, обнаруженных в разные годы во всех регионах средневековой Таврики. Из них только 3 экземпляра не введены в научный оборот, что позволяет избежать повторений. Бронзовые и $\checkmark$ деревянные просфорные штампы, имеющие ярко выраженное своеобразие, в данной работе не рассмаС్ триваются. Методы и материалы. Использованы стандартные методы сравнительного стилистического анализа. Анализ. Несмотря на то что каждый хлебный просфорный штамп, найденный на полуострове, обладает индивидуальными чертами, можно попытаться выделить несколько устойчивых стилистических 8 групп. Главным критерием при этом выступают особенности оформления предметов и расположение образующих композицию элементов. Результаты. Полученные данные позволили говорить о том, что на $\sum_{0}$ сегодняшний день выделяется 8 групп, в которых представлены штампы разной морфологии. Хроноло-
} 
гические рамки возникновения и периода существования каждой из этих групп различны. Отличаются и археологические комплексы, где изделия той или иной группы были зафиксированы. В количественном отношении группы так же не равномерны. Некоторые из них образуют единичные экземпляры просфор, другие - более многочисленны.

Ключевые слова: средневековая Таврика, хлебные штампы, орнаментация, хронология, стилистические группы.

Цитирование. Майко В. В. Керамические и каменные просфорные штампы Таврики. К вопросу о выделении стилистических групп // Вестник Волгоградского государственного университета. Серия 4, История. Регионоведение. Международные отношения. - 2021. - Т. 26, №6. - С. 19-30. - DOI: https://doi.org/10.15688/jvolsu4.2021.6.2

Введение. Среди литургических византийских предметов особую категорию составляют просфорные штампы. Несмотря на то что они получили распространение на территории Империи еще с позднеантичного и раннесредневекового времени, для средневековой Таврики эти изделия остаются редкой находкой. Практически все крымские штампы неоднократно опубликованы, а большая часть херсонесских находок [7; 8; 23], изделий восточного [11, c. 181-182], юго-западного [1, с. 428-429; 2 , c. 8; 3] и южного Крыма [4] проанализированы. За некоторым исключением каждый артефакт носит несомненные индивидуальные черты. Тем не менее попытка систематизации всего материала, предпринимаемая в этой работе впервые, наверное, имеет смысл. Именно она, с максимально полным привлечением опубликованных аналогий с других территорий, позволит, на наш взгляд, выделить стилистические группы штампов, зафиксированных на полуострове.

Источниковую базу работы на сегодняшний день составляют 33 изделия. 18 предметов найдено в Херсонесе. 4 известны благодаря дореволюционным исследованиям. Штампы 1896 и 1898 гг. из раскопок К.К. КосцюшкоВалюжинича в юго-восточном районе датированы VI в., археологический контекст до конца не ясен [9, с. 242, № 591; 16, с. 602, № 370, c. 604, № 372]. Археологический контекст находки, сделанной этим же ученым в 1905 г. у Карантинной бухты [9, с. 242-243, № 592], вообще неизвестен. Не просто реконструировать и контекст находки штампа 1909 г., происходящего из раскопок Р.X. Лёпера помещения XXXI на монастырском огороде [18, с. 96, рис. 1, 2]. Штамп, найденный П.П. Ефименко и переданный Г.Д. Белову [7, с. 206, рис. 8], является подъемным материалом, датированным X-XII веками. Контекст остальных находок известен. 2 штампа происходят из раскопок 1960 г. Н.В. Пятышевой общественного здания на участке водохранилища в слое, датированном VIII в. [18, с. 96, рис. 1, 3, с. 98, рис. 2, 4]. Три штампа найдены в 1963, 1969 и 1989 гг. экспедициями Л.Г. Колесниковой и А.И. Романчук в портовом районе в кладках и заполнениях жилых усадеб и площади перед «Храмом с аркосолиями». Два изделия с изображениями Святых традиционно датируются VI в. [16, с. 603, 605, № 371, 373], с крестообразной монограммой - XII в. [18, с. 96, рис. 1,1$]$. Наибольшая коллекция разнообразных штампов, состоящая из 8 экземпляров, зафиксирована при раскопках Л.В. Седиковой городского водохранилища в Южном районе, окончательная засыпь которого датируется по сопутствующему археологическому материалу первой половиной IX века. 3 экземпляра опубликовано [24, с. 511 , рис. 1 ; 22, с. 239 , рис. $134 ; 17$, рис. 39], четыре [19, рис. 15, 2] только упомянуты в литературе [20, с. 239; 23], фрагмент еще одного, с сюжетным изображением из этого же археологического объекта [21, рис. 33,2$]$ не введен пока в научный оборот.

В Керчи хлебных штампов обнаружено 2, к сожалению, оба вне археологического контекста [9, с. 243-244, № 593, 594]. Еще 2 изделия найдены в 2017 г. в объекте № 31, расположенном на участке квадрата П-26 участка № 209 салтово-маяцкого поселения Биели в пос. Октябрьский близ Керчи [14, с. 85, рис. 1, 4] и в 2015 г. в слое золистой супеси на участке раскопа «Восточный» синхронного поселения Белинское на территории Ленинского района $[15$, с. 321 , рис. 1,8$]$. В первом случае, в связи с отсутствием на исследованной территории памятника стратифицированных культурных напластований позднеантичного времени, штамп может датироваться в рамках VIII - рубежа IX/X веков. Предположительно этим же временем датируется и второй предмет. На террито- 
рии Восточного Крыма находки просфорных штампов единичны. Один, синхронный двум вышеуказанным, зафиксирован в комплексе гончарных печей салтово-маяцкого времени близ с. Лесное Судакского района [13, с. 190, рис. 1, 2], второй - в заполнении сооружения 7 раскопа XXII поселения Бакаташ II второй половины XIII- первой половины XIV в. [5, с. 348, ил. 18], третий является случайной находкой на территории Феодосии [6, с. 116, рис. 1, 4], археологический контекст которой неизвестен.

На территории крымского Южнобережья коллекцию хлебных штампов составляют всего две находки, зафиксированные при проведении подводных исследований в бухте пос. Карасан $[4$, c. 186 , рис. 1,2$]$ и при раскопках средневекового Алустона [10, рис. 6]. В первом случае основная масса сопутствующего материала датировалась второй половиной Х в., во втором изделие было обнаружено в переотложенных слоях XIII-XV вв., заполнявших помещение 69 внутрикрепостной застройки Алустона.

Более многочисленны штампы в Югозападном Крыму. По одному экземпляру найдено на Эски-Кермене в слоях гибели второй половины XIII в. усадьбы 1 на территории городища [1, с. 457 , рис. 25], Мангупе в синхронных материалах раскопок 1976 г. Мангупской базилики [3, с. 54, ил. 1] и с. Гончарное Бахчисарайского района с территории некрополя [12, c. 135 , рис. 1,1$]$ второй половины VIII - первой половины IX века. Три известняковых изделия зафиксировано при проведении раскопок на городище Бакла в 2003 г. при зачистке апсиды и наоса христианского храма второй половины VIII - первой половины IX в. [25, с. 283-284, рис. $6,1-3]$.

Имея описанную выше источниковую базу, в качестве критериев для выделения стилистических групп сложно использовать хронологический и, вероятно, бесполезно морфологический. Время появления различных категорий хлебных штампов, в том числе и глиняных, и время их бытования, исходя из «раритетности» изделий, установить всегда не просто, что неоднократно подчеркивалось специалистами [30, p. 594]. Формы этих артефактов самые разнообразные, от использования фрагментов керамики до технологически сложных составных изделий с разнообразными вариантами ручек. Исследователями была сделана попытка выделить изделия, безусловно, предназначенные для евхаристических целей. К решающим аргументам причисляют наличие формулы I $\Sigma$ X $\Sigma$ NI KA, в различных вариантах написания и изображения [29, S. 1-46; 33], присутствие в тексте легенды ЕҮЛОГІА, декорации в виде так называемого триумфального креста [34]. К сожалению, далеко не все штампы, в том числе и крымские, содержат легенды. На наш взгляд, логичнее всего применить не просто подобие изображений на предметах, а принцип сочетания христианских элементов на каждом конкретном изделии.

Методы. Для решения поставленных задач в работе используются методы, привлекаемые в исследовании археологических материалов. А именно: стратиграфический метод для определения относительной хронологии контекстов находок, типологический метод и стилистический анализ для группирования материала в соответствии с его морфологическими и стилистическими признаками, сравнительный метод для определения круга аналогий и культурной принадлежности артефактов.

Анализ. В первую стилистическую группу логично объединить хлебные штампы с изображениями Святых. Это два идентичных изделия с образом Святого Фоки, штампы с изображениями двух Святых, Святого Лонгина и фрагмент штампа с сюжетным изображением, реконструировать которое сложно (рис. $1,1-5$ ). Важно отметить, что все они содержали круговую легенду и обнаружены исключительно в центральном городе византийского Крыма Херсонесе. Не исключено, что они относятся к ранним произведениям подобного рода, датируемым VI в., но встречены и в контекстах более позднего времени. Аналогии им многочисленны.

Выделение остальных стилистических групп условно и по мере накопления материала может быть скорректировано. Во вторую группу можно отнести четыре изделия, происходящие из заполнения цистерны в Херсонесе. Композиция проста и состоит из разделенного на клетки поля с заполнением каждой рельефным крестом со слегка расширяющимися концами (рис. 1, б). Аналогии подобным штампам за пределами полуострова многочисленны. Прежде всего, вспомним штампы из Иерусалима, Афин и Аттики [31, p. 90-91, fig. 43-45], а также широко известный штамп 60-х гг. XIII в. 
из Монастыря Святой Екатерины на Синае [31, p. 88, fig. 42]. Близок и штамп из ближневосточных ранневизантийских материалов Иордании, вырезанный из известняка [32, p. 28 , fig. 25]. Важно отметить, что клетки в данном случае заполнены крупными мальтийскими крестиками с лучами в виде треугольников. Исходя исключительно из нескольких аналогий и палеографических особенностей текста, штамп датируется VI в. [32, p. 28], но очевидно его использование и в более позднее время.

Третья группа, наиболее многочисленная и разнообразная, характеризуется наличием центрального креста, и дополнительными крестиками в одном случае треугольниками, расположенными между лучами и олицетворявшими формулу I $\Sigma$ X $\Sigma$ NI KA. В настоящий момент можно говорить о следующих условных вариантах.

Вариант 1, близкий группе 2, пока отсутствующий в Крыму, составляют изделия из восточно-фракийского Галлиполи [27, s. 89, çiz. 1] и Итальянского Солето [26, p. 528, fig. 3], где центральный крест, разделенный на четыре сектора, заполнен дополнительными крестиками. На штампе из Солето между лучами креста - треугольники. Изделие из Галлиполи, исходя из археологического материала, датируется второй половиной $\mathrm{X}-\mathrm{XI}$ веком.

Вариант 2 представлен только тремя крымскими штампами, происходящими из Херсонеса, Керчи и Эски-Кермена (рис. 1, $7,10,13)$. Изделия из Керчи и Херсонеса полностью идентичны и различаются только наличием легенды у Херсонесского экземпляpa. В центре композиции у них расположен крест с расширяющимися концами, заполненными двумя рядами крестиков в квадратах. Между рукавами креста - четыре медальона с крестиками, в каковых В.Н. Залесская видит

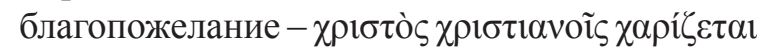
$\chi \alpha ́ \rho ı v$ (Христос дарует христианам благодать) [7, c. 206]. Не исключено, однако, что они все же символизируют формулу I $\Sigma$ X $\Sigma$ NI KA. Эски-Керменский штамп отличается тем, что центральный крест с почти прямыми лучами занимает большее пространство, разбит на меньшее число ячеек, а сами крестики имеют лучи в виде треугольников. Помимо этого в центральном средокрестии два наложенных один на другой креста, образующие подобие вось- милепестковой розетки. Аналогии этому варианту за пределами Крыма автору неизвестны.

Вариант 3 представлен на полуострове пока двумя экземплярами, один из которых зафиксирован при раскопках гончарных печей близ с. Лесное Судакского региона, второй, каменный - из раскопок некрополя у с. Гончарное Бахчисарайского района (рис. $1,8,11$ ).

В центре медальона Судакского изделия помещен круг диаметром 7 см, в который вписан крест с заметно расширяющимися сильно вогнутыми лучами, на краях которых помещены крупные точки - «слёзки». У «Бахчисарайского» - в двойной круг, украшенный зигзагом, помещен центральный крест с раздвоенными концами лучей.

Между лучами крестов обоих предметов диагонально расположены четыре мальтийских крестика с лучами в виде треугольников. На Судакском штампе композицию дополняют аналогичные, но меньшие по размеру кресты, повернутые на $90^{\circ}$ друг к другу, находящиеся в поле между вогнутыми лучами и обрамляющим кругом. На «Бахчисарайском» - крестики из пересекающихся линий с четырьмя точками между лучами, находящиеся по сторонам от «мальтийского» крестика. По технике нанесения все элементы Судакского штампа - литые, «Бахчисарайского» - выполнены врезной линией.

Среди ближневосточных штампов этой стилистической группы следует, прежде всего, вспомнить типологически наиболее близкую нашим мраморную находку примерно одинаковых размеров из частной американской коллекции $[13$, с. 190, рис. 1,3$]$. Типологически близок и восточно-средиземноморский штамп из коллекции Государственного Эрмитажа [9, с. 244, № 597]. Не исключено, что прообразом данного варианта просфор являются ближневосточные каменные и глиняные экземпляры с так называемым Несторианским крестом, прочерченным простыми пересекающимися линиями, с развернутыми в другой плоскости крестиками между лучами [31, p. 98, fig. 51].

К этому варианту примыкают три совершенно аналогичных штампа из Египта, Афин и Пальмиры, датирующиеся традиционно VI в., где между лучами креста с расширяющимися вогнутыми лучами в нижней части помещены характерные для этого варианта два крестика с лучами в виде треугольников, а в верхней - 
две стилизованные птицы [31, p. 122, fig. 68, $69 ; 4$, с. 186 , рис. 1,6$]$.

Вариант 4 образуют два идентичных штампа из случайных находок в Херсонесе и из материалов салтовского поселения Белинское (рис. 1, 9, 12). Совпадает не только изображение, но и круговая легенда. К этому же варианту можно отнести и штамп из водохранилища в Херсонесе, где центральный медальон заполнен крестом с расширяющимися лучами, четырехлепестковой розеткой в центре и крестиками на каждом из лучей, с лучами в виде треугольников. В радиально расходящихся от центра девяти секторах помещены аналогичные крестики (рис. 2, 1). И тут присутствует легенда, в которой определенно читаются два слова: «евлогия» и «Бога» [23].

В центре изделий из Белинского и Херсонеса в медальоне расположен крест с расширяющимися лучами, разделенными треугольниками. В радиально расходящихся от центра двенадцати секторах помещены крестики с лучами в виде треугольников. По мнению В.Н. Залесской, эти сектора с крестами могли символизировать двенадцать Апостолов [7]. По мнению исследовательницы, есть основания полагать, что Херсонесский штамп из случайных находок может свидетельствовать о связях Северного Причерноморья с монофиситским Востоком.

Вариант 5, выделение которого не бесспорно, составляют два изделия, происходящие из раскопок Херсонеса (рис. 2, 2, 3). На одном из них между лучами центрального креста с расширяющимися концами помещены трилистники, на другом к центральному кресту примыкают составные уголки разных размеров, образующие подобие восьмилепестковой розетки. Среди типологически близких изделий мы можем упомянуть только штамм из Иордании, штампующее поле которого составляет небрежно выполненная подлобными уголками шестилепестковая розетка [32, p. 23, fig. 9].

Четвертую группу, представленную на полуострове тремя находками из Карасанской бухты, поселения Бакаташ и городского водохранилища Херсонеса (рис. 2, 4-6), образуют штампы с центральным крестом с расширяющимися лучами. На Херсонесском предмете концы лучей подчеркнуты точками. Между лучами орнаментация отсутствует и в некоторых случаях заменена вогнутыми или выпуклыми треуголь- никами. Аналогии этой группе многочисленны. Совершенно идентичный Карасанскому штампу артефакт происходит из Египта [31, p. 37, fig. 18]. Типологически близкие известняковые экземпляры второй половины X - XI в., плоскость которых украшена разнообразными концентрическими ломаными линиями, характерными для этой категории изделий, известны в коллекции Британского музея [28, p. 161-163]. Отметим штамп из агоры Аргоса с хорошо выделенными треугольниками между лучами [34, p. 332, fig. 2] и особенно штамп из Египта [4, с. 186, рис. 1,3$]$, где треугольники между лучами выполнены в форме расширяющихся вогнутых лучей с точками на концах. Вместе с центральным крестом они образуют подобие восьмилепестковой розетки. О широком распространении данных штампов с простейшей системой орнаментации свидетельствуют и находки, сделанные при проведении раскопок 2003 г. христианского храма городища Бакла. Зафиксированные здесь три известняковых изделия с примитивно выполненным орнаментом (рис. 2, 7-9), вероятнее всего, являются местной продукцией.

Пятую группу образует пока единственный экземпляр из поселения Биели возле Керчи, вырезанный на отбитом основании ножки античной амфоры (рис. 2, 10). В медальоне было помещено изображение креста с прямыми практически не расширяющимися лучами. По центру креста толстой линией прочерчен еще один крест, делящий лучи на две равные части. Пространство между лучами представляет собой рельефные треугольники, разделенные прочерченной линией на две равные части. Наиболее близкие аналогии происходят из раскопок Северного участка Тмутараканского городища. Это два изделия, так же изготовленные из ножек античных амфор, на поверхности которых помещены изображения нескольких маленьких крестов. Исходя из археологического контекста, штампы были продатированы XI веком ${ }^{1}$.

Тем не менее это один из ранних видов штампов. Широко известны законсервированные хлебцы из раскопок Помпей с близкими по технике исполнения крестами [31, p. 27, fig. 8]. Ранним примером является крупное каменное изделие диаметром около 14 см из церкви Св. Стефана в Иерусалиме [31, p. 73, fig. 36]. Примером является и более поздний экземпляр 
из Солето, так же, как и наш, вырезанный на ножке амфоры [31, p. 61, fig. 29]. Известны подобные штампы и на ножках красноглиняных позднеантичных светильников. Совершенно очевидно, что этот простой крест использовался на протяжении всего раннего средневековья.

Шестую группу образует так же пока единственный двойной штамп из случайных находок в Керчи (рис. 2, 11). На одной его стороне помещен крест с раздвоенными концами лучей. Между двумя верхними расположены две крупные точки, между нижними - две вертикальные слегка изогнутые линии. На другой стороне штампа нанесена шестилепестковая розетка, образованная тремя пересекающимися в центре линиями. Аналогии на территории Таврики нам неизвестны. За ее пределами, в частности, в коллекции музея Спийкенисс в Нидерландах, присутствует двойной глиняный штамп, датирующийся XI-XII вв., с крестом с раздвоенными концами, между которыми с одной из сторон помещены точки $[12$, с. 135 , рис. 1,2$]$. Обратим внимание и на хорошо известный штамп из Олимпии, датируемый VI в., с изображением между лучами креста, украшенного крестиками, луны, угла, треугольника и аналогичной шестилепестковой розетки [31, p. 57, fig. 26]. Наибольшее количество аналогий с изображением простого креста с двумя верхними точками между лучами [32, р. 23 , fig. 8] и в виде шестилепестковой розетки [32, p. 22, fig. 5] известно пока в Иордании.

Седьмая группа также представлена пока одним изделием. Это двусторонний штамп из раскопок Херсонеса (рис. 2, 13). На обеих сторонах предмета по хорошо просушенной глине вырезаны монограммы, расшифровывающиеся, как имя святого Феодора, в родительном падеже. Авторами публикации находка была аргументированно связана с христианским храмом и продатирована XII в. [18, с. 95-96]. Штампы с монограммами немногочисленны, но достаточно хорошо известны. Вспомним хотя бы две находки с территории Восточного Средиземноморья, хранящиеся в Государственном Эрмитаже [9, с. 244-245, № 598, 599].

Восьмая группа ввиду малочисленности и уникальности материала выделена условно. Входящие в нее каменные изделия хронологически наиболее поздние, датирующиеся не ранее второй половины XIV в., и, почти на- верняка, местного производства. Во-первых, это штамп, предположительно происходящий из находок при строительстве Феодосийского порта в начале XX в. (рис. 2, 14). Это, по мнению автора публикации [6, с. 116], модель храма Святого Димитрия в Феодосии. Основание храма с рельефным простым крестом с треугольниками между лучами использовалось в качестве хлебного штампа. Типологически и функционально в эту группу есть смысл отнести и штамп из Алустона (рис. 2, 15), выполненный в виде октагонального византийского храма так же с вырезанным на основании простым крестом с точками между лучами.

Два штампа из Херсонеса 1909 и 1960 гг. (рис. 2, 12, 16), исходя из фрагментарности, отнести к конкретному варианту сложно. Уникальным остается хлебный штамп, использовавшийся при византийском обряде изобличения вора [3, с. 54, ил. 1], найденный в 1976 г. при раскопках Мангупской базилики. Этот штамп так же трудно отнести к какой-либо группе, ибо, исходя из его функционального назначения, была сделана только центральная часть композиции, а вместо остальных элементов помещена надпись.

Результаты. В результате проведенного анализа удалось предварительно выделить восемь групп хлебных штампов, найденных в византийской Таврике. Зависимость между морфологией, системой орнаментации и посвятительными греческими легендами на известных нам экземплярах не прослеживается. Помимо изделий с изображениями Святых, заслуживающих отдельного анализа, в качестве базовых орнаментальных мотивов надо отметить наличие на штампующем поле клеток, заполненных крестиками, центрального креста с дополнительной орнаментацией между лучами, креста с дополнительной орнаментацией в виде радиально расходящихся от центра секторов, креста различных вариантов без орнаментации, монограммы, лепестковой розетки. Все эти мотивы вполне могли иметь особое символическое обрядовое значение.

\section{ПРИМЕЧАНИЕ}

${ }^{1}$ Информация, любезно предоставленная Э.Р. Устаевой, из раскопок которой и происходят указанные находки. 

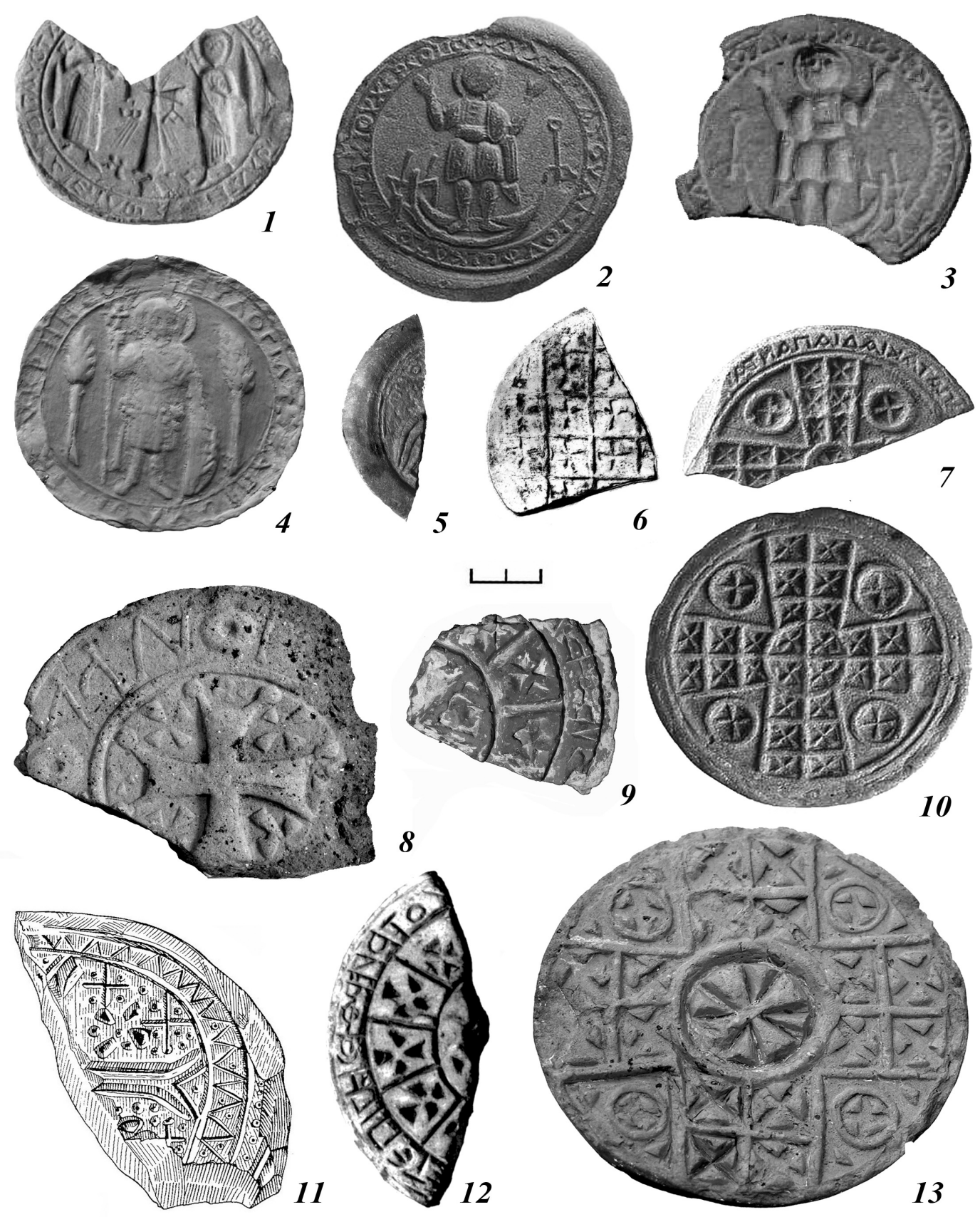

Рис. 1. Византийские хлебные штампы Таврики групп 1-3:

1-7, 12 - Херсонес 1898, 1896, 1963, 1989, 1994, 1993, 1905, 1988 гг.; 8- близ с. Лесное; 9 - поселение Белинское;

10 - Керчь 1859 г.; 11 - с. Гончарное; 13 - Эски-Кермен

Fig. 1. Byzantine bread stamps of Taurica, groups 1-3:

1-7, 12 - Chersonesos 1898, 1896, 1963, 1989, 1994, 1993, 1905, 1988; 8 - near Lesnoe village; 9 - Belinskoye settlement;

10 - Kerch 1859; 11 - Goncharnoe village; 13 - Eski-Kermen 

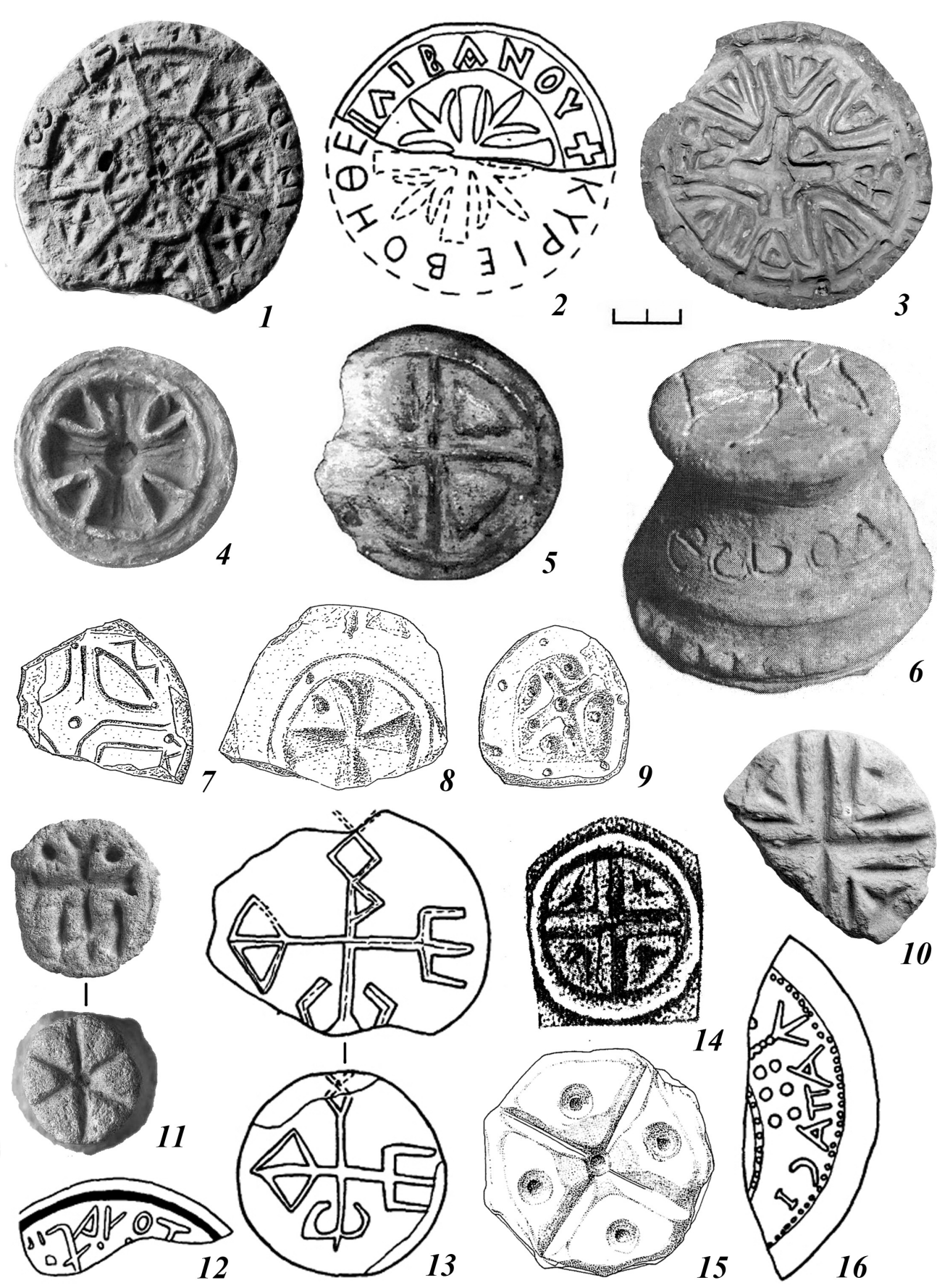

Рис. 2. Византийские хлебные штампы Таврики групп 3-8:

1-3, 6, 12, 13, 16 - Херсонес 1994, 1960, 1994, 1988, 1960, 1969, 1909 гг.; 4 - бухта Карасан; 5 - поселение Бакаташ II; 7-9 - Бакла; 10 - поселение Биели; 11 - Керчь 1982 г.; 14 - Каффа; 15 - Алустон

Fig. 2. Byzantine bread stamps of Taurica, groups 3-8:

1-3, 6, 12, 13, 16 - Chersonesos 1994, 1960, 1994, 1988, 1960, 1969, 1909; 4 - Karasan Bay; 5 - Bakatash II settlement; 7-9-Bakla; 10 - Biyeli settlement; 11 - Kerch 1982; 14 - Caffa; 15 - Aluston 


\section{СПИСОК ЛИТЕРАТУРЫ}

1. Айбабин, А. И. Позднесредневековая часовня на плато Эски-Кермена / А. И. Айбабин, Э. А. Хайрединова // Материалы по археологии, истории и этнографии Таврии. - 2011. Вып. XVII. - C. 422-457.

2. Айбабин, А. И. Предметы христианского культа из раскопок 2003-2008 гг. на городище Эски-Кермен / А. И. Айбабин, Э. А. Хайрединова

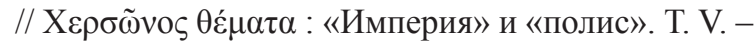
Севастополь : Национальный заповедник «Херсонес Таврический», 2013. - С. 6-9.

3. Виноградов, А. Ю. «Апокрифическая» надпись с Мангупа и обряды «изобличения вора»: магия и право между Античностью и Средневековьем / А. Ю. Виноградов, М. С. Желтов // Slovĕne. 2015. - T. 4, № 1. - C. 52-93.

4. Герасимов, В. Е. О находке просфорного штампа на месте кораблекрушения X-XI вв. в Карасанской бухте у мыса Плака в Крыму / В. Е. Герасимов, Э. Ястршебовска // Древняя и средневековая Таврика. Археологический альманах. - 2012. № 28. - C. 185-187.

5. Гукин, В. Д. Фрагмент стеатитовой иконы рубежа XI-XII веков из предместья средневекового Солхата / В. Д. Гукин // Труды Государственного Эрмитажа. - 2008. - T. XLII : Византия в контексте мировой культуры. - С. 342-350.

6. Денисюк, В. Л. Штамп для церковных просфор из Феодосии - Каффы из собрания Одесского Археологического музея НАН Украины / В. Л. Денисюк // Боспор Киммерийский и варварский мир в период античности и средневековья. Ремесла и промыслы. - Керчь : Керч. город. тип., 2010. C. 112-116.

7. Залесская, В. Н. Памятники средневековой греческой эпиграфики из Северного Причерноморья (новые поступления византийского отделения Эрмитажа) / В. Н. Залесская // Византийский временник. - 1988. - № 49 (74). - С. 204-207.

8. Залесская, В. Н. Литургические штампыевлогии (Св. Лонгин Криний и Св. Мамант Кипрский) / В. Н. Залесская // Литургия, архитектура и искусство византийского мира. - СПб. : Византинороссика, 1995. - С. 236-242.

9. Залесская, В. Н. Памятники византийского прикладного искусства IV-VII веков. Каталог коллекции / В. Н. Залесская. - СПб. : Изд-во Гос. Эрмитажа, 2006. - 272 с.

10. Кирилко, В. П. Октогональный храм Мангупа / В. П. Кирилко, В. Л. Мыц // Античная древность и средние века. - 2001. - Вып. 32. - С. 354-375.

11. Майко, В. В. Восточный Крым во второй половине X - XII в. / В. В. Майко. - Киев : Вид. Олег Філюк, 2014. - 467 с.
12. Майко, В. В. Археологические материалы второй половины X - ХІІ в. в юго-западном Крыму / В. В. Майко // Ученые записки Крымского федерального университета имени В.И. Вернадского. Серия «История. Исторические науки». - 2016. Т. 2 (68), № 1. - С. 134-148.

13. Майко, В. В. Византийский хлебный штамп из раскопок комплекса гончарных печей возле с. Лесное Судакского региона / В. В. Май-

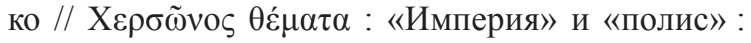
XIII Междунар. византийский семинар. - Симферополь : Типография «Ариал», 2021. - С. 185-190.

14. Майко, В. В. Просфорный штамп из раскопок средневекового поселения Биели / В. В. Майко, Ю. Л. Белик // Таврические студии. - 2018. № 16 . - С. $84-88$.

15. Майко, В. В. Раннесредневековые материалы городища «Белинское» в Восточном Крыму / В. В. Майко, В. Г. Зубарев, С. В. Ярцев // Древности Боспора. - 2016. - Т. 20. - С. 320-329.

16. Наследие византийского Херсона / ред. Т. Яшаева [и др.]. - Севастополь : Телескоп ; Остин : Ин-т класс. археологии Техас. ун-та, 2011. - 704 с.

17. Романчук, А. И. Исследования ХерсонесаХерсона. Раскопки. Гипотезы. Проблемы. Т. 2 : Византийский город / А. И. Романчук. - Тюмень : Изд-во Тюмен. гос. ун-та : Компания Мир, 2008. $544 \mathrm{c}$.

18. Романчук, А. И. Несколько надписей на средневековой керамике Херсонеса / А. И. Романчук, Э. И. Соломоник // Византийский временник. 1987. - Т. 48. - C. 95-100.

19. Седикова, Л. В. Отчет о раскопках водохранилища в Херсонесе в 1993 году / Л. В. Седикова // Научный архив ФГБУН «Институт археологии Крыма РАН». - Инв. кн. № 3. - Инв. № 277. - Папка № 586. - 10 л.

20. Седикова, Л. В. Раскопки водохранилища в Херсонесе / Л. В. Седикова // Археологические исследования в Крыму. 1993 год. - Симферополь : Таврия, 1994. - С. 238-240.

21. Седикова, Л. В. Отчет о раскопках водохранилища в Херсонесе в 1994 году / Л. В. Седикова // Научный архив ФГБУН «Институт археологии Крыма РАН». - Инв. кн. № 3. - Инв. № 349. - Папка № 684. -32 л.

22. Седикова, Л. В. Раскопки водохранилища в Херсонесе / Л. В. Седикова // Археологические исследования в Крыму. 1994 год. - Симферополь : Изд-во «Харьков», 1997. - С. 238-239.

23. Седикова, Л. В. Штампы для изготовления литургического хлеба из Херсонеса / Л. В. Седико-

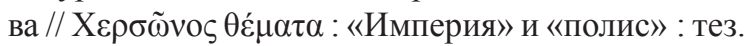
докл. и сообщ. IV Междунар. византийского семинара. - Севастополь : Национальный заповедник «Херсонес Таврический», 2012. - С. 35-36. 
24. Седикова, Л. В. Надписи на средневековой керамике из раскопок водохранилища в Херсонесе / Л. В. Седикова, В. А. Сидоренко // Материалы по археологии, истории и этнографии Таврии. 1996. - Вып. V. - C. 106-110, 511-515.

25. Юрочкин, В. Ю. Новые христианские памятники «пещерного города» Бакла в Крымской Готии / В. Ю. Юрочкин // Северное и Западное Причерноморье в античную эпоху и средневековье. - Симферополь : Таврия, 2009. - С. 275-311.

26. Arthur, P. Uno stampo eucaristico bizantino da Soleto / P. Arthur // Archeologia medievale. - 1997. XXIV. - P. 525-530.

27. Çaylak Türker, A. Gelibolu'da Bizans seramikleri ve ökaristik ekmek damgasi / A. Çaylak Türker // Hacettepe Üniversitesi Edebiyat Fakültesi Dergisi. 2005. - № 22 (2). - S. 87-104.

28. Dalton, O. M. Catalogue of Early Christian Antiquities and Objects from Christian East in the Department of British and Mediaeval Antiquities and Ethnography of the British Museum / O. M. Dalton. London : British Museum, 1901. - 186 p.

29. Dölger, F. J. Heidnische und christliche Brotstempel mit religiösen Zeichen. Zur Geschichte des Hostienstempels / F. J. Dölger // Antike und Christentum. - 1929. - Vol. I. - S. 1-46.

30. Feig, N. A Byzantine Bread Stamp from Tiberias / N. Feig // Studium Biblicum Franciscanum. Liber Annuus. - 1994. - Vol. XLIV. - P. 591-594.

31. Galavaris, G. Bread and the Liturgy : The Symbolism of Early Christian and Byzantine Bread Stamps / G. Galavaris. - London : University of Wisconsin Press, 1970. - 235 p.

32. Kakish, R. Ancient Bread Stamps from Jordan / R. Kakish // Mediterranean Archaeology and Archaeometry. - 2014. - Vol. 14, № 2. - P. 19-31.

33. Spitzing, G. Brot / Brotstempel / G. Spitzing // Lexikon byzantinisch-christlicher Symbole. Die Bilderwelt Griechenlands und Kleinasien.-München : Diederichs, 1989. - S. 65-67.

34. Varalis, Y. D. Un sceau paléochrétien de pain eucharistique de l'Agora d'Argos / Y. D. Varalis // Bulletin de Correspondance Hellénique. - 1994. Vol. 118, livr. 2. - P. 331-342.

\section{REFERENCES}

1. Aibabin A.I., Khairedinova E.A. Pozdnesrednevekovaya chasovnya na plato EskiKermena [Late Medieval Chapel on the Eski-Kermen Plateau]. Materialy po arkheologii, istorii i etnografii Tavrii [Materials in the Archaeology, History and Ethnography of Tauria], 2011, iss. 17, pp. 422-457.

2. Aibabin A.I., Khairedinova E.A. Predmet khristianskogo kulta iz raskopok 2003-2008 gg. na gorodishche Eski-Kermen [Objects of a Christian
Cult from Excavation of 2003-2008 on the Ancient Settlement Eski-Kermen]. Chersōnos themata: «Imperiya» $i$ «polis» [Chersonos themata: "Empire and Polis"]. Sevastopol, Natsionalnyy zapovednik «Khersones Tavricheskiy», 2013, vol. 5. pp. 6-9.

3. Vinogradov A.Yu., Zheltov M.S. «Apokrificheskaya» nadpis s Mangupa i obryady «izoblicheniya vora»: magiya i pravo mezhdu Antichnostyu i Srednevekovem ["Apocryphal" Inscription from Mangup and the Rites of "Denunciation of the Thief": Magic and Law Between Antiquity and the Middle Ages]. Slověne, 2015, vol. 4, no. 1, pp. 52-93.

4. Gerasimov V.E., Yastrshebovska E. O nakhodke prosfornogo shtampa na meste korablekrusheniya X-XI vv. v Karasanskoy bukhte u mysa Plaka v Krymu [On the Find of a Prosphore Stamp at the Site of the Shipwreck of the $10^{\text {th }}-11^{\text {th }}$ Centuries in Karasan Bay Near Cape Plaka in Crimea]. Drevnyaya $i$ srednevekovaya Tavrika. Arkheologicheskiy almanakh [Ancient and Medieval Taurica. Archaeological Almanac], 2012, no. 28, pp. 185-187.

5. Gukin V.D. Fragment steatitovoy ikony rubezha XI-XII vekov iz predmestya srednevekovogo Solkhata [A Fragment of the Steatite Icon of the Turn of the $11^{\text {th }}-12^{\text {th }}$ Centuries from the Suburbs of Medieval Solhat]. Trudy Gosudarstvennogo Ermitazha [Proceedings of the State Hermitage], 2008, vol. 42: Vizantiya v kontekste mirovoy kultury [Byzantium in the Context of World Culture], pp. 342-350.

6. Denisyuk V.L. Shtamp dlya tserkovnykh prosfor iz Feodosii - Kaffy iz sobraniya Odesskogo Arkheologicheskogo muzeya NAN Ukrainy [Stamp for Church Prosphores from Feodosia - Kaffa from the Collection of the Odessa Archaeological Museum of the National Academy of Sciences of Ukraine]. Bospor Kimmeriyskiy $i$ varvarskiy mir $v$ period antichnosti $i$ srednevekovya. Remesla i promysly [Bospor Kimmerian and Barbaric World in the Period of Antiquity and Middle Ages. Crafts and Fisheries]. Kerch, Kerchenskaya gorodskaya tipografiya, 2010, pp. 112-116.

7. Zalesskaya V.N. Pamyatniki srednevekovoy grecheskoy epigrafiki iz Severnogo Prichernomorya (novye postupleniya vizantiyskogo otdeleniya Ermitazha) [Monuments of Medieval Greek Epigraphy from the Northern Black Sea Region (New Receipts of the Byzantine Branch of the Hermitage)]. Vizantiiskii vremennik [Byzantina Chronika], 1988, no. 49 (74), pp. 204-207.

8. Zalesskaya V.N. Liturgicheskie shtampyevlogii (Sv. Longin Kriniy i Sv. Mamant Kiprskiy) [Liturgical Stamps-Eulogies (St. Longin Crinius and St. Mamant of Cyprus)]. Liturgiya, arkhitektura $i$ iskusstvo vizantiyskogo mira [Liturgy, Architecture and Art of the Byzantine World]. Saint Petersburg, Vizantinorossika Publ., 1995, pp. 236-242. 
9. Zalesskaya V.N. Pamyatniki vizantiyskogo prikladnogo iskusstva IV-VII vekov. Katalog kollektsii [Monuments of Byzantine Applied Art of the $4^{\text {th }}$ $7^{\text {th }}$ Centuries. Collection Directory]. Saint Petersburg, Izd-vo Gosudarstvennogo Ermitazha, 2006. 272 p.

10. Kirilko V.P., Myts V.L. Oktogonalnyy khram Mangupa [The Orthogonal Temple of Mangup]. Antichnaya drevnost $i$ srednie veka [Antiquity and the Middle Ages], 2001, iss. 32, pp. 354-375.

11. Maiko V.V. Vostochnyy Krym vo vtoroy polovine $X-X I I v$. [Eastern Crimea in the Second Half of the $10^{\text {th }}-12^{\text {th }}$ Centuries]. Kiev, Vyd. Oleg Filiuk, 2014. 467 p.

12. Maiko V.V. Arkheologicheskie materialy vtoroy poloviny X - XII v. v yugo-zapadnom Krymu [Materials of the Second Half of $10^{\text {th }}-12^{\text {th }} \mathrm{c}$. in the South-West Crimea]. Uchenye zapiski Krymskogo federalnogo universiteta imeni V.I. Vernadskogo. Seriya «Istoriya. Istoricheskie nauki» [Scientific Notes of the Crimean Federal University Named After V.I. Vernadsky. Series "History. Historical Sciences"], 2016, vol. 2 (68), no. 1, pp. 134-148.

13. Maiko V.V. Vizantiyskiy khlebnyy shtamp iz raskopok kompleksa goncharnykh pechey vozle s. Lesnoe Sudakskogo regiona [A Byzantine Bread Stamp Excavated from the Complex of Pottery Kilns Near the Village of Lesnoe in the Sudak Region]. Chersōnos themata: «Imperiya» $i$ «polis». XIII Mezhdunar. vizantiyskiy seminar [Chersonos themata: "Empire" and "Polis". The $13^{\text {th }}$ International Byzantine Seminar]. Simferopol, Tipografiya «Arial», 2021, pp. 185-190.

14. Maiko V.V., Belik Yu.L. Prosfornyy shtamp iz raskopok srednevekovogo poseleniya Bieli [A Prosphora Stamp from the Excavations of the Medieval Settlement of Bieli]. Tavricheskie studii [Tauride Studies], 2018, no. 16, pp. 84-88.

15. Maiko V.V., Zubarev V.G., Yartsev S.V. Rannesrednevekovye materialy gorodishcha «Belinskoe» v Vostochnom Krymu [Early Medieval Materials of the Belinskoye Settlement in the Eastern Crimea]. Drevnosti Bospora [Antiquities of Bosporus], 2016, vol. 20, pp. 320-329.

16. Yashaeva T. et al., eds. Nasledie vizantiyskogo Khersona [The Legacy of Byzantine Cherson]. Sevastopol, Teleskop Publ.; Austin, Institut klassicheskoy arkheologii Tekhasskogo universiteta, 2011. 704 p.

17. Romanchuk A.I. Issledovaniya KhersonesaKhersona. Raskopki. Gipotezy. Problemy. T. 2: Vizantiyskiy gorod [Research of Chersonesos-Cherson. Excavations. Hypotheses. Problems. Vol. 2. Byzantine City]. Tyumen, Izd-vo Tyumenskogo gosudarstvennogo universiteta, Kompaniya Mir Publ., 2008. 544 p.

18. Romanchuk A.I., Solomonik E.I. Neskolko nadpisey na srednevekovoy keramike Khersonesa [Several Inscriptions on Medieval Ceramics of
Chersonesos]. Vizantiyskiy vremennik [Byzantina Chronika], 1987, vol. 48, pp. 95-100.

19. Sedikova L.V. Otchet o raskopkah vodokhranilishcha v Khersonese v 1993 godu [Report on the Excavation of the Reservoir in Chersonesos in 1993]. Nauchnyy arkhiv FGBUN «Institut arkheologii Kryma RAN» [Scientific Archive of FSBIS "Institute of Archaeology of Crimea RAS"], inventory book no. 3, inventory no. 277, folder no. 586, 101.

20. Sedikova L.V. Raskopki vodokhranilishcha $\mathrm{v}$ Khersonese [Excavations of the Reservoir in Chersonesos]. Arkheologicheskie issledovaniya $v$ Krymu. 1993 god [Archaeological Research in Crimea. 1993]. Simferopol, Tavriya Publ., 1994, pp. 238-240.

21. Sedikova L.V. Otchet o raskopkah vodokhranilishcha v Khersonese v 1994 godu [Report on the Excavation of the Reservoir in Chersonesos in 1994]. Nauchnyy arkhiv FGBUN «Institut arkheologii Kryma RAN» [Scientific Archive of FSBIS "Institute of Archaeology of Crimea RAS"], inventory book no. 3, inventory no. 349, folder no. 684, 321.

22. Sedikova L.V. Raskopki vodokhranilishcha $\mathrm{v}$ Khersonese [Excavations of the Reservoir in Chersonesos]. Arkheologicheskie issledovaniya $v$ Krymu. 1994 god [Archaeological Research in Crimea. 1994]. Simferopol, Izd-vo «Kharkov», 1997, pp. 238239.

23. Sedikova L.V. Shtampy dlya izgotovleniya liturgicheskogo khleba iz Khersonesa [Stamps for the Manufacture of Liturgical Bread from Chersonesos]. Chersōnos themata: «Imperiya» $i$ «polis»: tez. dokl. i soobshch. IV Mezhdunar. vizantiyskogo seminara [Chersonos Themata: "Empire" and "Polis". Abstracts of Reports and Communications of the $4^{\text {th }}$ International Byzantine Seminar]. Sevastopol, Natsionalnyy zapovednik «Khersones Tavricheskiy», 2012, pp. 35-36.

24. Sedikova L.V., Sidorenko V.A. Nadpisi na srednevekovoy keramike iz raskopok vodokhranilishha $\mathrm{v}$ Khersonese [Inscriptions on Medieval Ceramics from Excavations of the Reservoir in Chersonesos]. Materialy po arkheologii, istorii $i$ etnografii Tavrii [Materials in Archaeology, History and Ethnography of Tauria], 1996, iss. 5, pp. 106-110, 511-515.

25. Yurochkin V.Yu. Novye khristianskie pamyatniki «peshchernogo goroda» Bakla v Krymskoy Gotii [New Christian Monuments of the "Cave City" of Bakla in Crimean Gothia]. Severnoe i Zapadnoe Prichernomore $v$ antichnuyu epokhu i srednevekove [Northern and Western Black Sea Region in the Ancient Era and Middle Ages]. Simferopol, Tavriya Publ., 2009, pp. 275-311.

26. Arthur P. Uno stampo eucaristico bizantino da Soleto. Archeologia medievale, 1997, 24, pp. 525-530.

27. Çaylak Türker A. Gelibolu'da Bizans seramikleri ve ökaristik ekmek damgasi. Hacettepe Üni- 


\section{ВИЗАНТИЙСКАЯ ТАВРИКА}

versitesi Edebiyat Fakültesi Dergisi, 2005, no. 22 (2), S. 87-104.

28. Dalton O.M. Catalogue of Early Christian Antiquities and Objects from Christian East in the Department of British and Mediaeval Antiquities and Ethnography of the British Museum. London, British Museum, 1901. $186 \mathrm{p}$.

29. DölgerF.J.Heidnischeund christlicheBrotstempel mit religiösen Zeichen. Zur Geschichte des Hostienstempels. Antike und Christentum, 1929, Bd. 1, S. 1-46.

30. Feig N. A Byzantine Bread Stamp from Tiberias. Studium Biblicum Franciscanum. Liber Annuus, 1994, vol. 44, pp. 591-594.
31. Galavaris G. Bread and the Liturgy: The Symbolism of Early Christian and Byzantine Bread Stamps. London, University of Wisconsin Press, 1970. 235 p.

32. Kakish R. Ancient Bread Stamps from Jordan. Mediterranean Archaeology and Archaeometry, 2014, vol. 14, no. 2, pp. 19-31.

33. Spitzing G. Brot / Brotstempel. Lexikon byzantinisch-christlicher Symbole. Die Bilderwelt Griechenlands und Kleinasien. München, Diederichs, 1989, S. 65-67.

34. Varalis Y.D. Un sceau paléochrétien de pain eucharistique de l'agora d'Argos. Bulletin de Correspondance Hellénique, 1994, vol. 118, livr. 2, pp. 331-342.

\section{Information About the Author}

Vadim V. Maiko, Doctor of Sciences (History), Director, Institute of Archaeology of Crimea of the Russian Academy of Sciences, Prosp. Akademika Vernadskogo, 2, 295007 Simferopol, Russian Federation, vadimmaiko1966@mail.ru, https://orcid.org/0000-0003-1065-4836

\section{Информация об авторе}

Вадим Владиславович Майко, доктор исторических наук, директор, Институт археологии Крыма РАН, просп. Академика Вернадского, 2, 295007 г. Симферополь, Российская Федерация, vadimmaiko1966@mail.ru, https://orcid.org/0000-0003-1065-4836 